\title{
Urban Forestry Legislation in Ontario
}

\section{John W. Andresen}

\author{
Urban Forestry Studies Programme \\ Faculty of Forestry and Landscape Architecture \\ University of Toronto, Toronto, Ontario M5S 1A1
}

\begin{abstract}
Ontario's urban trees and forests lack comprehensive protection under contemporary legislation and regulation. Although the Ontario Municipal Act enables any municipality to compose and enforce tree by-laws, only larger municipal governments have enacted tree protection legislation, often based upon the Plant Diseases Act. In general, municipal trees are more subject to removal than conservation. Increased civic activism, however, has alerted municipal officials to investigate more adequate tree protection legislation. Results of a survey of municipal tree policies, regulations and by-laws is presented.
\end{abstract}

\section{Résumé}

Les arbres urbains et forêts urbaines de I'Ontario ne sont pas protégés dans leur ensemble par la législation et les règlements actuels. Bien que l'Acte Municipal de l'Ontario permette aux municipalités de promulguer et de mettre en vigueur des arrêtés concernant les arbres, seuls les gouvernements municipaux les plus importants ont décrété des mesures législatives pour la protection des arbres, en se basant le plus souvent sur l'Acte des Epiphyties (Plant Diseases Act). En général, les arbres municipaux sont plutôt sujets à l'abattage qu'à la conservation. Toutefois, un activisme grandissant au niveau du public pousse les autorités municipales à la recherche d'une législation plus adéquate pour la protection des arbres. Les résultats d'une enquête sur les politiques municipales, règlements et arrêtés concernant les arbres sont présentés pour conclure.

\section{Introduction}

At the Humber College public forum on "Trees in the City" Swaigen (1973) discussed Ontario legislation that affects the status of cultivated and naturally established trees. His general conclusions were that:

(1) existing legislation offers little to place a high priority on the preservation of trees and greenspace; and

(2) contemporary legislation provides broad discretion to all levels of government to cut trees and exploit greenspace with little or no accountability to the citizenry.

Further, he stated "While there is an abundance of legislation aimed at punishing the person who defaces individual trees, there is little duty imposed on developers, either private or public, to conserve trees and greenspace or to account for them in their planning procedures".

During a panel discussion on "The Case for Urban Vegetation" held at the 1974 International Public Works Congress, Andresen (1975) noted that archaic or inflexible shade tree protection 1. Andresen, J.W. 1976. Greenspace conservation - persuasion and
regulation. Talk given to: Canada Committee on Ecological Land Classification, Urban Ecology Workshop, 24 November 1976. by-laws discourage or hamper cooperation by contractors and builders. $\mathrm{He}$ also indicated that when by-law violations do occur, there is a lack of, or extended delay in, prosecution of offenders by the courts.

The present paper will review the legislative options available to municipalities. The review is supported by an analysis of municipal forestry legislative needs.

Managers of urban vegetation are confronted by a serious legislative dilemma (Andresen $1976^{1}$ ). A typical parks department responding to municipal Council, is often obliged to sacrifice sound, mature trees to accommodate urban redevelopment. On the other hand, the same department is expected to preserve a city's trees but is constrained by public works engineers who usually have the final word.

With the recognition of the ecological movement, which gained international momentum at the close of the 1960's, a new body of environmental law rapidly emerged (Baldwin and Page 1970). This environmental and legal concern is directly applicable to the conservation and preservation of urban trees. Since we often look to Britain for legal precedents it is worth noting England's Tree Preservation Order (Hall 1970). These regulations, enacted under the British Town and Country Planning Act of 1968, are probably the most comprehensive of any tree and forest conservation measures in the Western World. Provisions of the Order, which protect privately as well as publicly owned amenity trees and forests, might well be adapted to and incorporated within existing or proposed Ontario tree legislation.

There are few federal statutes that apply directly to the conservation and protection of urban trees. The Forestry Research $\mathrm{Act}^{2}$ enables the Canadian Forestry Service to provide advisory and research assistance to agencies or individuals to encourage better municipal tree management. And the Railway $\mathrm{Act}^{3}$ gives the nation's railroad carriers authority to manage trees and forests along specified right-of-way corridors whether on rural or urban land. The provinces and their municipal governments may enact tree-protection and related land development statutes and by-laws.

At the Ontario Provincial level a number of statutes specifically apply to the regulation of tree management practices or permit local control of tree resources. The Trees Act ${ }^{4}$ as written and usually interpreted, protects trees from trespass and illegal cutting on wooded sites of two or more acres. This Act would be of interest and value to the increasing number of resident owners of suburban woodlots and the absentee urban owner of a rural wooded site. The majority of the

2. Revised Statutes of Canada 1970, Chapter F-30.

3. Revised Statutes of Canada 1970, Chapter R-2.

4. Revised Statutes of Ontario 1970, Chapter 468. 
trees on the small residential lots of Ontario's 8.8 million urbanites, however, are not protected by the Act. Litigation involving trees on privately owned urban land seldom takes the form of prosecutions against those who injure trees, or civil actions for injunctions against destruction of trees. Most cases are civil suits for compensation for property damage or physical injuries caused by trees or large branches falling on objects such as vehicles, dwellings and utility wires.

Section 457 of The Ontario Municipal Act $^{5}$ is more urban oriented than the Trees Act but still offers little to conserve or protect privately owned trees. As implied by the title of the Act, trees under consideration would have to be municipally controlled or owned. Municipal Councils are authorized to pass by-laws to preserve and protect municipal trees, plant trees along municipal roads, enter private property to prune or remove hazard trees and otherwise manage trees for the public good. Other Ontario laws and Acts such as the Environmental Protection Act, the new Environmental Assessment Act, and the Planning Act (now under review) have general reference to land development but are ill-defined regarding conservation of trees, either public or private. Note should be made of the provisions within the Ontario Power Corporation Act (as amended) that allows Ontario Hydro to thwart sections of other Acts and municipal by-laws. Ontario Hydro is specifically empowered to enter any land on either side of a hydro right-of-way or works and fell, prune or remove any trees that the Corporation feels is necessary. It should be observed, however, that pruning and removal practices are improving and that detrimental environmental impact is decreasing.

The primary defect in the Ontario legislative scheme, especially in relation to tree conservation in and near metropolitan areas is that "The Acts [described above] give municipalities and expropriating authorities broad discretion to destroy trees, with no corresponding duty to plant, replant, or relocate. While municipalities are empowered to pass tree-protection by-laws, they have no duty to pass such by-laws or to enforce the ones they have". (Swaigen 1973).

Further to Swaigen's lament, municipal tree bylaws and municipal departmental regulations have not been catalogued or inventoried, nor has a comprehensive assessment been made of legislative effectiveness. To gain a better understanding by-law legislation in Ontario and to determine what corrective measures or reforms are needed to enhance the legal standing of trees (Stone 1975) the Ontario Shade Tree Council (OSTC) requested specific tree by-law data from municipal officials. Results of the survey follow.

\section{Results: A Municipal Tree By-Law Survey Under the sponsorship of the Association of}

5. Revised Statutes of Ontario 1970, Chapter 284.

6. Revised Statutes of Ontario 1970, Chapter 354. the Municipalities of Ontario (AMO) and the OSTC, 670 of the 832 upper and lower tier Ontario municipalities were surveyed. Upper tier governments include metropolitan, district and regional municipalities, established and restructured counties and improvement districts. Lower tier governments include those listed in Table 1 . There is considerable overlap in population numbers in moving down the demographic scale from city to improvement district.

Each municipality was asked some 90 questions to establish a profile of municipal, tree management policies and practices. Eight of the questions were specifically designed to analyze tree by-law comprehension and use. The sample size of 670 coincided with the dues paying membership (mailing labels available) of AMO. (Those municipalities not affiliated with $\mathrm{AMO}$ are primarily county governments, villages under 1,000 in population and township governments with fewer than 1,000 people per square mile.) Responses to the tree by-law questions came from 399 different municipal governments. Their answers provided a reasonable estimate of tree by-law presence, need and related data.

Survey Results. Of those governmental representatives responding to the questionnaire, those of Ontario's cities and boroughs were the most active and interested in tree by-law application (Table 1). Tree inventories, upon which tree management and ultimately tree by-law legislation are based, for all classes of government were few or lacking especially for towns, villages and townships. Most municipalities incorporated tree removal policies within their operational programmes, but in contrast, policies to protect trees were usually lacking except for some $47 \%$ of the cities and boroughs. Allocation of specific funds for tree planting and maintanance work was closely related to the interest in tree protection. Finally, the majority of the officials of town, city, borough and upper tier governments were prepared to initiate new tree programmes if provincial or federal funds became available. Correspondingly, the same groups were interested in receiving tree by-law and related information. Between 30 and $43 \%$ of the villages and townships were also concerned with aid programmes and information.

Interpretation: A diagnosis of the data in Table 1 leads one to conclude that the 56 villages and 207 townships that responded (and probably those who did not reply) require immediate fiscal and educational help to conserve and protect their urban tree resources. As indicated, tree-related by-laws at these two levels of government were few in number and tree inventories were nonexistent. No attempt was made to distinguish between Dutch elm disease motivated and other tree oriented by-laws. Lack of concern in current tree protection programmes is also reflected in the passive interest to gain additional funding and extension assistance. It should be recalled, though, that most village and township public 
Table 1. Tree by-law and related data derived from Ontario municipal forestry survey (Andresen 1976)

\begin{tabular}{|c|c|c|c|c|c|}
\hline Response category & $\begin{array}{l}\text { City or } \\
\text { Borough }\end{array}$ & Town & Village & Township & $\begin{array}{l}\text { Upper Tier } \\
\text { Municipality }\end{array}$ \\
\hline $\begin{array}{l}\text { Responses by numbers } \\
\text { Total population. ....... } \ldots \ldots \ldots \ldots \ldots \ldots \ldots \ldots \\
\text { Total number of governments } \ldots \ldots \ldots \ldots \ldots \ldots \ldots \ldots \\
\text { No. of govts. responding } \ldots \ldots \ldots \ldots \ldots \ldots\end{array}$ & $\begin{array}{r}5,179,040 \\
44 \\
34 \\
\end{array}$ & $\begin{array}{r}1,161,162 \\
142 \\
80\end{array}$ & $\begin{array}{r}129,189 \\
121 \\
56\end{array}$ & $\begin{array}{r}1,398,451 \\
486 \\
207 \\
\end{array}$ & $\begin{array}{r}\text { N/A } \\
39 \\
22\end{array}$ \\
\hline 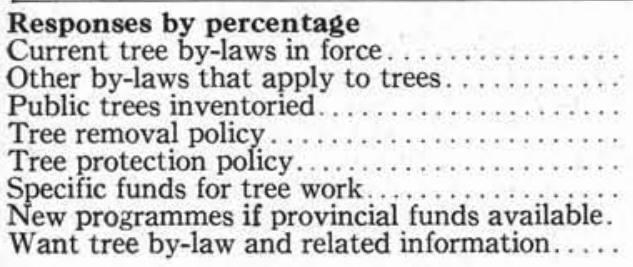 & $\begin{array}{l}29.4 \\
47.1 \\
26.5 \\
76.5 \\
47.1 \\
50.0 \\
70.6 \\
88.2\end{array}$ & $\begin{array}{r}10.0 \\
15.0 \\
2.5 \\
47.5 \\
10.0 \\
11.3 \\
68.8 \\
67.5\end{array}$ & $\begin{array}{r}0.0 \\
7.1 \\
0.0 \\
26.8 \\
1.8 \\
1.8 \\
42.9 \\
39.3\end{array}$ & $\begin{array}{r}2.9 \\
16.0 \\
0.5 \\
19.3 \\
2.9 \\
2.9 \\
29.5 \\
38.2\end{array}$ & $\begin{array}{r}9.1 \\
22.7 \\
13.6 \\
50.0 \\
18.2 \\
9.1 \\
45.5 \\
63.6\end{array}$ \\
\hline
\end{tabular}

1. Demographic source: Ministry of Treasury, Economic and Intergovernmental Affairs (1975). Includes improvement districts and separate towns.

trees are located on through roads and not on residential streets. Well-treed and maintained village parks are few and far between.

Tree removal policies vis-à-vis tree protection policies further reinforce Swaigen's (1973) observation that tree removal programmes are of much more municipal concern than tree conservation endeavours. It was encouraging, however, to learn that the larger municipalities that include most of Ontario's citizenry are responsive to programmes and information that would enhance their public tree programmes.

As an observation tree conservation and protection by-laws are either needed or require updating; ways and means to fund municipal forestry programmes must be found; and one or more provincial agencies or professional organizations should take the lead to provide guidance and assistance to those municipalities in need.

In an enlightened society, conservation of urban dominated natural resources can be accomplished through several endeavours or alternatives. The ideal would incorporate maximum civic participation and support with minimum bureaucratic control; least desirable would be rigid municipal control backed by punitive legislation. This latter alternative would probably inhibit or stifle rational resource development and discourage or exclude public interest. Realistically, in our contemporary Canadian context, an approach to conserving our urban trees seems to thread a compromise path between the two extremes.

\section{Assistance and Reform}

Two major endeavours are now underway to meet the tree by-law needs and information requirements of Ontario's municipal governments (the other provinces are invited to share in the results). The first is a Canadian Forestry Service sponsored project by the Canadian Environmental Law Association and the University of Toronto Urban Forestry Studies Programme to review all relevant legislation applicable to urban tree management, recommend reform of tree legislation to bring older laws into current reality, and to com- pose a model tree by-law that can be adapted to local use by the several classes of government listed in Table 1. Several versions of the model by-law are now under review. A formal, public report should be ready for distribution in the autumn of 1977 .

As the second major programme, the Ontario Shade Tree Council will soon release a comprehensive urban tree information brochure. The brochure will include a summary listing of agencies, organizations and references available to individual citizens and municipalities concerned with the conservation and management of Ontario's trees and forests.

In closing, and in relation to the urban forestry theme of this issue of the Forestry Chronicle, the reader is reminded that adequate tree by-law legislation and regulation are essential components of an urban forestry programme of any level of government. Further, there seems to be an upwelling of civic interest to better manage urban tree resources and greenspaces of Ontario's (and Canada's) metropolitan centres. With these thoughts in mind it behooves all professional foresters to become better acquainted with the problems of municipal forest management and to assist in solving urban forestry problems.

\section{Acknowledgements}

Messrs. J. Swaigen and P. Lewis-Watts reviewed and contributed to this paper.

\section{References}

Andresen, J. W. 1975. Legal and educational implications. Amer. Public Works Asso. Rpt. 42(6):6.

$$
\text { 1976. Urban forestry in Ontario - }
$$
municipal challenges and opportunities. Report on file with Forest Man. Branch, Ontario Min. Nat. Res.

Baldwin, M. F. and J. F. Page, Jr. Eds. 1970. Law and the environment. Walker and Co. New York.

Hall, T. H. R. Ed. 1970. Tree preservation orders. Arboricultural Asso. Advis. Leafl. No. 1.

Ministry of Treasury, Economics and Intergovernmental Affairs. 1975. Municipal Directory. Queen's Printer, Toronto.

Stone, C. D. 1975. Should trees have standing? Avon Books, New York.

Swaigen, J. 1973. Current Ontario legislation and trees. Canadian Environmental Law Asso., Toronto. 